onvoldoende heeft gemotiveerd. In hoger beroep bleek namelijk dat de verdachte op 14 september 2015 opnieuw aangehouden is, terwijl het onderhavige dossier (in de hier te bespreken zaak) reeds gesloten was op 28 juli 2015 en op 10 augustus 2015 ten parkette is ontvangen. Op 15 september 2015 ontving de raadsman vervolgens van zijn secretaresse een telefoonnotitie dat de zaak geseponeerd zou zijn. Het was de raadsman niet duidelijk of dit een politiesepot of een sepot van het openbaar ministerie is geweest. Het hof droeg de A-G op nader onderzoek te verrichten naar de gang van zaken. Daaruit bleek dat de hernieuwde aanhouding in september 2015 een vergissing was. De signalering van verdachte stond ten onrechte nog open. Er is toen besloten tot een 'sepot 02 '. 18

Op basis hiervan oordeelde het hof dat geen sprake is van een situatie die is te bestempelen als een uitzonderlijk geval waarin de vervolging wordt ingesteld of voortgezet nadat door het openbaar ministerie gedane, of aan het openbaar ministerie toe te rekenen, uitlatingen (of daarmee gelijk te stellen gedragingen) bij de verdachte het gerechtvaardigde vertrouwen hebben gewekt dat hij niet (verder) zal worden vervolgd. Dat verwarring bij de raadsman c.q. verdachte is ontstaan nadat eerder een piketmelding op nummer van de onderhavige strafzaak was gedaan, doet daar niet aan af, mede in aanmerking genomen dat de raadsman na de vermeende sepotmededeling heeft aangegeven de verdachte in een latere fase na 14 september 2015 nog te hebben gesproken en met (het onderdeel) ZSM van het openbaar ministerie contact te hebben gehad. Met name bij het laatstgenoemde contact had de raadsman de gelegenheid om eventuele onduidelijkheden (van wie is het sepot afkomstig en voor welke zaak?) te verhelderen. Een en ander had, volgens het hof, voor de raadsman aanleiding moeten zijn om bij een bevoegd persoon binnen het openbaar ministerie, bijvoorbeeld bij de officier van justitie, nadere informatie in te winnen over de status van de zaak. Dit is niet gebeurd.

Beroep op het vertrouwensbeginsel slaagt weliswaar zelden, maar het mag niet te makkelijk worden verworpen. Door in het midden te laten of het overgelegde bericht ('Parket Breda belde inz. [verdachte]. Zaak wordt geseponeerd.') een juiste en volledige weergave bevat van wat kennelijk door of namens de officier van justitie telefonisch aan de secretaresse van de raadsman is medegedeeld, heeft het hof eveneens in het midden gelaten of een (eventuele) onjuiste of onvolledige weergave van de desbetreffende mededeling aan het openbaar ministerie moet worden toegerekend, dan wel voor rekening dient te komen van de verdachte, terwijl het in zijn oordeel wel omstandigheden heeft betrokken waarvan het niet heeft vastgesteld dat deze omstandigheden kenbaar waren voor de verdediging ten tijde van de

18. 'Het lijkt er op dat er, destijds, een signalering voor verdachte [verdachte] open is blijven staan. [verdachte] is toen aangehouden voor diefstal en heling, waarvoor hij op 16 juni 2015 al verhoord was. Er is toen, zoals ik in het systeem kan zien ook een sepot formulier opgemakkt, dit geld echter alleen voor die "onterechte aanhouding". Vandaar de verwarring in dit dossier.' gedane mededeling. Het hof heeft aldus de verwerping van het verweer niet toereikend gemotiveerd.

\section{NTS 2020/35}

\author{
HR 11 februari 2020, 18/03411, \\ ECLI:NL:HR:2020:222
}

\begin{abstract}
Gebruikmaken van een tolk die niet is ingeschreven in het Register beëdigde tolken en vertalers en het schriftelijk vastleggen van de redenen daarvoor a.b.i. art. $28.4 \mathrm{Wet}$ beëdigde tolken en vertalers
\end{abstract}

\section{Aantekening redactie}

De verdachte in deze zaak is door Hof Den Haag wegens verkrachting veroordeeld tot een gevangenisstraf van twee jaar. Het middel klaagde dat tijdens de zitting in hoger beroep in strijd met de wet gebruik is gemaakt van een niet in het Register beëdigde tolken en vertalers ingeschreven tolk, zonder dat daaraan een geldige reden ten grondslag lag, althans dat de reden voor afwijking van de afnameplicht onvoldoende is gemotiveerd. Het is van groot belang dat binnen de strafrechtsketen enkel gebruik wordt gemaakt van gerechtstolken en beëdigd vertalers waarvan de kwaliteit en integriteit gewaarborgd is. Via een afnameplicht wordt gewaarborgd dat ook enkel van deze gerechtstolken en beëdigd vertalers gebruik wordt gemaakt. Artikel 28 Wet beëdigde tolken en vertalers maakt echter wel mogelijk dat gebruik wordt gemaakt van een niet in het Register beëdigde tolken en vertalers ingeschreven tolk of vertaler. Het betreft hierbij de situatie dat een gerechtstolk of beëdigd vertaler niet of niet tijdig beschikbaar is. Dit is op zich voor de hand liggend nu een verdachte op grond van de wet en op basis van artikel 6 EVRM nu eenmaal recht heeft op een tolk of vertaler. Indien dus geen gerechtstolk of beëdigd vertaler beschikbaar is, zal gebruik gemaakt (moeten) worden van een tolk of vertaler die niet in het register staat ingeschreven. Dit moet dan wel voorzien van een motivering schriftelijk worden vastgelegd. ${ }^{19}$ Op deze wijze kan in het vervolg van een procedure worden nagegaan wie als tolk of vertaler is opgetreden. Dit biedt enerzijds een waarborg dat zorgvuldig met de afnameverplichting wordt omgegaan en biedt voorts duidelijkheid wie als tolk of vertaler heeft gefungeerd. ${ }^{20}$ Was in de onderhavige zaak voldaan aan

19. Zie lid 1, 3 en 4 van art. 28 Wet beëdigde tolken en vertalers.

20. Kamerstukken II 2004/05, 29936, nr. 3, p. 23-24. 
deze plicht? Het proces-verbaal van de zitting in hoger beroep hield het volgende in:

'Ter terechtzitting is anwwezig [betrokkene 1], geboren op [geboortedatum] 1966, wonende te [plaats], tolk in de Tunesische taal, die niet in het Register beëdigde tolken en vertalers is ingeschreven. $N u$ een in het Register ingeschreven tolk in deze taal niet (tijdig) beschikbaar was, wordt al hetgeen ter terechtzitting is gesproken of voorgelezen door voornoemde tolk vertolkt. Alvorens met zijn werkzaamheden aan te vangen, legt de tolk in handen van de voorzitter op de bij de wet voorgeschreven wijze de eed af dat hij zijn taak naar zijn geweten zal vervullen.

\section{$(\ldots)$}

De raadsvrouw voert het woord tot verdediging overeenkomstig haar overgelegde en aan dit proces-verbaal gehechte pleitnotities.

In aanvulling daarop voert de raadsvrouw aan:

Omdat het hof de laatste feitelijke instantie is, wilde cliënt graag worden bijgestaan door een tolk. Hij hoopte dat hij daardoor beter zijn visie op de zaak zou kunnen overbrengen. Hij heeft er geen rekening mee gehouden dat dit vragen zou oproepen of afbreuk aan de betrouwbaarheid van zijn verklaringen zou doen. Cliënt blijft bij zijn eerder afgelegde verklaringen.'

Volgens de Hoge Raad heeft het hof hiermee toereikend de redenen vastgelegd als bedoeld in artikel 28 lid 4 Wet beëdigde tolken en vertalers. Tot een nadere motivering was het hof niet gehouden, mede in aanmerking genomen dat blijkens het proces-verbaal van de terechtzitting in hoger beroep door of namens de verdachte geen bezwaren zijn ingebracht tegen het gebruik maken van de daar anwezige tolk. Door de raadsvrouw werd niets aangevoerd waaruit zou kunnen blijken dat verdachte benadeeld zou zijn door het gebruik maken van een niet in het register ingeschreven tolk.

\section{NTS 2020/36}

HR 11 februari 2020, 18/04435, ECLI:NL:HR:2020:229

Strafmotivering ex art. 359.6 Sv inzake niet meer in Nederland verblijvende Mongoolse verdachte

\section{Aantekening redactie}

De feitenrechter is - uiteraard binnen de grenzen van het ter zake geldende strafmaximum - vrij in de keuze van de straf, waaronder ook is te verstaan de keuze van de strafsoort, en in de waardering van de factoren die hij daartoe van belang acht. ${ }^{21}$ Wat betreft de oplegging van een onvoorwaardelijke vrijheidsbenemende sanctie is het in artikel 359 lid 6, eerste volzin, Sv weergegeven motiveringsvereiste zo ingevuld dat uit de strafmotivering expliciet moet blijken dat de rechter onder ogen heeft gezien dat hij een straf of maatregel oplegt die onvoorwaardelijke vrijheidsbeneming met zich brengt. De rechter dient dit te doen door in de strafmotivering tot uitdrukking te brengen dat zo'n sanctie wordt opgelegd en die sanctieoplegging te verbinden met in de strafmotivering opgegeven redenen. ${ }^{22}$ In het onderhavige geval heeft het hof vastgesteld dat de verdachte is geboren in Mongolië en geen bekende woon- of verblijfplaats in Nederland heeft. Het hof heeft de verdachte veroordeeld tot een gevangenisstraf van vijf maanden wegens meerdere diefstallen en een diefstal met geweld en daaraan ten grondslag gelegd dat dit een passende sanctie is omdat het naar het oordeel van het hof, zoals de politierechter heeft overwogen, 'gaat om een buitenlandse verdachte die niet meer in Nederland verblijft' en 'waaraan geen andere strafmodaliteit kan worden opgelegd'. In de toelichting op het middel werd angevoerd dat hof in strijd met artikel 359 lid 5 en $6 \mathrm{~Sv}$ niet in het bijzonder de redenen heeft gegeven die de straf hebben bepaald respectievelijk tot de keuze voor een vrijheidsbenemende straf hebben geleid. Het ontging de steller van het middel waarom geen andere strafmodaliteit (dan een onvoorwaardelijke gevangenisstraf) kon worden opgelegd aan een buitenlandse verdachte die niet (meer) in Nederland verblijft. De politierechter had weliswaar overwogen dat een gevangenis(straf) een passende sanctie is, maar heeft niet, althans niet begrijpelijk, uitgelegd waarom de vrijheidsbeneming in dit geval passend was. $\mathrm{Nu}$ mag de rechter volgens de Hoge Raad bij zijn keuze in de strafoplegging weliswaar betrekken of het reëel is dat een bepaalde straf(modaliteit) ook zal (kunnen) worden tenuitvoergelegd, maar dat betekent nog niet dat daarmee die straf(modaliteit) niet 'kan' worden opgelegd. ${ }^{23}$ Bovendien valt niet zonder meer in te zien waarom bij een gevangenisstraf in het onderhavige geval wel een (reëel) vooruitzicht bestaat op tenuitvoerlegging en bij een taakstraf dan wel een geldboete niet. Uit de strafmotivering bleek ook niet genoegzaam waarom niet kon worden volstaan met een voorwaardelijke gevangenisstraf (dan wel toepassing van art. 9a Sr). De Hoge Raad overweegt dan ook: 'Door de enkele verwijzing naar de omstandigheid dat "verdachte kennelijk niet meer in Nederland verblijft", heeft het hof de strafoplegging niet toereikend gemotiveerd.'

21. Zie HR 15 januari 2019, ECLI:NL:HR:2019:46 en HR 21 november 2006, ECLI:NL:HR:2006:AY7805

22. Bijv. HR 27 september 2016, ECLI:NL:HR:2016:2191.

23. VgI. HR 15 januari 2019, ECLI:NL:HR:2019:46. 